\title{
Nitrogen Fertilization Strategies Suitable to Achieve the Quality Requirements of Wheat for Biscuit Production
}

\author{
Massimo Blandino,* Federico Marinaccio, Patrizia Vaccino, and Amedeo Reyneri
}

\begin{abstract}
A low grain protein content (GPC) and flour strength (W) are desirable traits for wheat (Triticum aestivum L.) for biscuit production. Nitrogen fertilization is the main factor that affects storage proteins. The aim of this study was to compare the effect of different commonly applied $\mathrm{N}$ fertilization strategies on the quality requirements of common wheat intended for biscuits production. Field experiments were set up over three growing seasons at three sites in northwestern Italy on two wheat cultivars. Three $\mathrm{N}$ rates $(100$, 130 , and $170 \mathrm{~kg} \mathrm{~N} \mathrm{ha}^{-1}$ ), applied split as ammonium nitrate, have been compared to a slow release fertilizer, applied only at tillering $\left(130 \mathrm{~kg} \mathrm{~N} \mathrm{ha}^{-1}\right)$. The leaf greenness, grain yield, grain and flour protein content, and $\mathrm{W}$ were affected directly by the rate of $\mathrm{N}$ distributed as ammonium nitrate in several of compared agro-environments. Taking in account the same $\mathrm{N}$ rate, the application of a slow release fertilizer resulted in a significantly lower GPC (4\%), W (6\%), and flour stability measured through the Brabender farinograph (10\%) compared to the split fertilization with ammonium nitrate, while no difference was observed for ear density and grain yield. Suitable rheological parameters of wheat for biscuits could be achieved through the split application of ammonium nitrate only at low $\mathrm{N}$ rate, but this could limit their productive performances. Conversely, the fertilization strategy of applying a slow release fertilizer at tillering is able to better satisfy the qualitative requirements for biscuit production, without causing any grain yield loss.
\end{abstract}

The wheat GPC is one of the key quality factors that can influence the end-use of wheat market classes throughout the world. Unlike improver or superior bread-making wheat, which require high levels of protein, a low grain protein $(<10.5 \%)$ is desirable for the wheat for biscuit, (Italian wheat quality classification; Foca et al., 2007), also called soft red or soft white wheat (Farrer et al., 2006).

Good biscuit-making quality has been defined in terms of soft kernel texture, a low percentage of vitreous kernel, low protein content, weak-gluten grains, and low water retention capacity (Gaines, 1991). Since biscuit dough is less extensible and more elastic than bread dough, due to the lower water level, biscuits retract after cooking, and the absence of retraction is considered a criterion of good quality (Contamine et al., 1995; Pedersen et al., 2004). Labuschagne et al. (1997) reported a significant negative correlation between biscuit diameter after cooking and the content of flour protein and the Chopin

\section{Blandino, F. Marinaccio, and A. Reyneri, Univ. of Turin, Dipartimento di Scienze Agrarie, Forestali e Alimentari, Largo Paolo Braccini 2, 10095, Grugliasco (TO), Italy; and P. Vaccino, Consiglio per la Ricerca in Agricoltura e l'Analisi dell'Economia Agraria, Unità di ricerca per la Selezione dei Cereali e la Valorizzazione delle varietà vegetali (CRA-SCV), via Forlani 3, 26866, S. Angelo Lodigiano (LO), Italy. Received 11 Dec. 2014. Accepted 8 Apr. 2015. *Corresponding author (massimo.blandino@unito.it).}

Published in Agron. J. 107:1584-1594 (2015)

doi:10.2134/agronj14.0627

Available freely online through the author-supported open access option. Copyright (C) 2015 by the American Society of Agronomy, 5585 Guilford Road, Madison, WI 53711. All rights reserved. No part of this periodical may be reproduced or transmitted in any form or by any means, electronic or mechanical, including photocopying, recording, or any information storage and retrieval system, without permission in writing from the publisher. alveograph $\mathrm{P} / \mathrm{L}$ ratio. As far as biscuit-making is concerned, Igrejas et al. (2002) stated that the total content of grain protein is more important than their composition on the quality of these end-products.

Due to the growing sanitary and technological requirements of industry, the cultivation of wheat for biscuits is occurring even more under chain agreements, with prices similar and sometimes higher than those of the other wheat qualitative categories. Thus, it becomes more important to find the best crop practices that could fit the requirements of this wheat category supply chain.

A first key factor that is indispensable to obtain good biscuit quality wheat is the use of cultivars characterized by high grain softness and the capacity of accumulating specific storage proteins, and in particular high molecular glutenin sub-units (Huebner et al., 1999; Pedersen et al., 2004). Furthermore, the GPC in wheat for biscuit cultivars is highly variable across growing seasons and environments, and could often be too high compared to the end-use quality requirements of this market class (Farrer et al., 2006). Moreover, wheat supply chains are looking for more homogenous lots, in terms of GPC, as the high variability of rheological parameters has a negative impact on the marketing of this wheat category.

Nitrogen content is widely considered as the main factor that can directly affect storage proteins, as well as the technological quality of grain (Wieser and Seilmeier, 1998). As is well known, a direct relationship exists between the $\mathrm{N}$ fertilizer

Abbreviations: AULGC, area under the leaf greenness curve; CEC, cation exchange capacity; GDDs, growing degree days; GPC, grain protein content, GS, grow th stage; HNT, Hydro N-Tester; TKW, thousand kernel weight; TW, test weight. 
rates and the GPC in wheat (Garrido-Lestache et al., 2004). High grain protein levels in wheat could be attributed in part to excessive $\mathrm{N}$ application rates, which farmers apply to obtain a higher grain yield. Thus, for this wheat category, it is necessary to find a compromise for $\mathrm{N}$ management between the quantitative and the qualitative aspects. This means to identify the proper $\mathrm{N}$ application rate to allow producers to maintain grain productivity, and to reduce the risk of exceeding the grain protein levels for biscuit production.

In several winter wheat production temperate areas, $\mathrm{N}$ is generally split between tillering at the growth stage (GS) 23 (Zadoks et al., 1974) and the beginning of stem elongation (GS 31-32). Dividing the total N application into two or more treatments can help growers enhance nutrient efficiency, promote optimum wheat yields and mitigate the loss of nutrients related to high spring precipitations (López-Bellido et al., 2005).

The use of "special" fertilizers, such as controlled or slow release fertilizers could be an alternative to reducing the $\mathrm{N}$ loss in the environment, since they minimize $\mathrm{N}$ leaching, especially in sandy and shallow soils (Wang and Alva, 1996). Moreover, since the nutritive release is gradual during the growing season, the use of these fertilizers could simplify the operative management of $\mathrm{N}$ fertilization, and reduce the number of field applications.

Although the effect of these special fertilizers on environmental $\mathrm{N}$ pollution and losses have been well documented (Dinnes et al., 2002), few studies have reported the impact of using slow release fertilizers on grain yield and GPC. In particular, the effect of a slow release fertilizer on rheological properties of wheat for biscuits has not yet been studied.

The aim of this study was to determine, in different pedo-climatic conditions, the effect of different $\mathrm{N}$ fertilization strategies on the quality requirements of common wheat intended for biscuits production, to enhance the quality traits of this commercial category, and obtain a lower flour variability of the rheological parameters.

\section{MATERIALS AND METHODS}

\section{Experimental Site and Treatments}

The study was performed in northwestern Italy (Piedmont Region), during three growing seasons (2007-2008, 20082009, and 2009-2010). The experiment was performed in three sites (Table 1):

- sandy loam soil, Typic Hapludalfs (USDA classification), in Cigliano (VC province), characterized by a shallow soil with a low cation exchange capacity (CEC),

- silt loam, Aquic Frugiudalf in Quargnento (AL province), a deep soil with high CEC but low fertility (low content of organic matter),

- sandy silt loam soil, Typic Udifluvents in Poirino (TO province), a deep soil with medium CEC and fertility.

In each trial, the compared treatments were factorial combinations of:

- four $\mathrm{N}$ granular fertilization strategies: three $\mathrm{N}$ rates (100, 130 , and $170 \mathrm{~kg} \mathrm{~N} \mathrm{ha}^{-1}$ ) applied as ammonium nitrate split between tillering (GS 23) and stem elongation in

Table I. Main physical and chemical characteristics of the soils considered in the field experiments carried out in three growing seasons between 2007 and 2010 in northwestern Italy.

\begin{tabular}{|c|c|c|c|c|}
\hline Parameters & Unit & Cigliano (VC) & Quargnento (AL) & Poirino (TO) \\
\hline Geographic coordinates & & $45^{\circ} 18^{\prime} \mathrm{N}, 8^{\circ} 0 \mathrm{I}^{\prime} \mathrm{E}$ & $44^{\circ} 57^{\prime} \mathrm{N}, 8^{\circ} 29^{\prime} \mathrm{E}$ & $44^{\circ} 54^{\prime} \mathrm{N}, 7^{\circ} 24^{\prime} \mathrm{E}$ \\
\hline Altitude & $\mathrm{m}$ & 237 & $|2|$ & 262 \\
\hline Soil texture & & sandy loam & silt loam & sandy silt loam \\
\hline Soil (USDA classification) & & Typic Hapludalfs & Aquic Frugiudalf & Typic Udifluvents \\
\hline Sand $(2-0.05 \mathrm{~mm})$ & $\%$ & 50.7 & 9.8 & 20.5 \\
\hline Silt (0.05- $0.002 \mathrm{~mm})$ & $\%$ & 38.9 & 70.0 & 64.7 \\
\hline Clay $(<0.002 \mathrm{~mm})$ & $\%$ & 10.4 & 20.2 & 14.9 \\
\hline $\mathrm{pH}$ & & 6.2 & 5.5 & 6.3 \\
\hline Organic matter & $\%$ & 1.47 & 1.09 & 1.25 \\
\hline $\mathrm{C} / \mathrm{N}$ & & 10.7 & 9.6 & 11.0 \\
\hline Cation exchange capacity (CEC) & $\mathrm{cmol} \mathrm{kg}^{-1}$ & 0.92 & 1.65 & 1.45 \\
\hline Exchangeable $\mathrm{K}$ & $\mathrm{mg} \mathrm{kg}^{-1}$ & 59 & 56 & 66 \\
\hline Available P & $\mathrm{mg} \mathrm{kg-1}$ & 28 & 52 & 20 \\
\hline \multicolumn{5}{|l|}{ Total $\mathrm{N}$} \\
\hline 2007-2008 & $\%$ & 0.091 & 0.060 & 0.069 \\
\hline 2008-2009 & $\%$ & 0.077 & 0.056 & 0.062 \\
\hline $2009-2010$ & $\%$ & 0.080 & 0.065 & 0.070 \\
\hline \multicolumn{5}{|c|}{ AULGC in unfertilized control $(0 \mathrm{~N}) \dagger$} \\
\hline $2007-2008$ & HNT $\ddagger$ value & 17,002 & 17,596 & 19,236 \\
\hline 2008-2009 & HNT value & 12,615 & 11,668 & 11,642 \\
\hline $2009-2010$ & HNT value & 14,807 & 9,872 & 14,375 \\
\hline \multicolumn{5}{|c|}{ Grain yield in unfertilized control $(0 \mathrm{~N}) \dagger$} \\
\hline $2007-2008$ & $\mathrm{tha}^{-1}$ & 5.8 & 5.8 & 5.6 \\
\hline 2008-2009 & $\mathrm{tha}^{-1}$ & 1.8 & 1.4 & 1.6 \\
\hline $2009-2010$ & $\mathrm{tha}^{-1}$ & 4.1 & 2.6 & 2.3 \\
\hline
\end{tabular}

† Data reported for area under leaf greenness curve (AULGC) and grain yield are the average of two cultivars (Artico and Paledor) and four replications for each cultivar. Soil was sampled from a depth of 0 to $60 \mathrm{~cm}$ using Eijkelkamp cylindrical augers.

$\ddagger$ HNT, Hydro-N-Tester. 
Table 2. Main trial information and timing of $\mathrm{N}$ fertilization for the field experiments conducted in three growing seasons between 2007 and 2010 in northwestern Italy.

\begin{tabular}{|c|c|c|c|c|c|}
\hline \multirow[b]{2}{*}{ Site } & \multirow[b]{2}{*}{ Crop techniques } & \multirow[b]{2}{*}{ Timing of fertilization } & \multicolumn{3}{|c|}{ Growing season } \\
\hline & & & 2007-2008 & 2008-2009 & $2009-2010$ \\
\hline Cigliano & Sowing date & & 5 Nov. 2007 & I7 Nov. 2008 & 4 Nov. 2009 \\
\hline \multirow[t]{4}{*}{ sandy loam } & $\mathrm{N}$ fertilization & tillering (GS 23) & 6 Mar. 2008 & II Mar. 2009 & 16 Mar. 2010 \\
\hline & & stem elongation (GS 32) † & 6 Apr. 2008 & 8 Apr. 2009 & 14 Apr. 2010 \\
\hline & Fungicide & & 14 May 2008 & I8 May 2009 & 17 May 2010 \\
\hline & Harvest date & & 2 July 2008 & 30 June 2009 & 8 July 2010 \\
\hline Quargnento & Sowing date & & 15 Nov. 2007 & 3 Nov. 2008 & 25 Oct. 2009 \\
\hline \multirow[t]{4}{*}{ silt loam } & $\mathrm{N}$ fertilization & tillering (GS 23) & 21 Mar. 2008 & 16 Mar. 2009 & 19 Mar. 2010 \\
\hline & & stem elongation (GS 32) † & 8 Apr. 2008 & 20 Apr. 2009 & 16 Apr. 2010 \\
\hline & Fungicide & & 16 May 2008 & 10 May 2009 & 19 May 2010 \\
\hline & Harvest date & & I 5 July 2008 & 3 July 2009 & 2 July 2010 \\
\hline Poirino & Sowing date & & 3 Nov. 2007 & 10 Nov. 2008 & 30 Oct. 2009 \\
\hline \multirow[t]{4}{*}{ sandy silt loam } & $\mathrm{N}$ fertilization & tillering (GS 23) & 10 Mar. 2008 & 18 Mar. 2009 & 18 Mar. 2010 \\
\hline & & stem elongation (GS 32) † & 4 Apr. 2008 & 17 Apr. 2009 & 20 Apr. 2010 \\
\hline & Fungicide & & I 5 May 2008 & I8 May 2009 & 19 May 2010 \\
\hline & Harvest date & & 9 July 2008 & 9 July 2009 & 15 July 2010 \\
\hline
\end{tabular}

† For only TI, T2, and T3 treatments.

the following proportions (GS 32): 50-50 (T1), 50-80 (T2), 50-120 (T3) $\mathrm{kg} \mathrm{N} \mathrm{ha}^{-1}$, were compared with a slow release fertilizer (T4), applied only at tillering (GS 23, $130 \mathrm{~kg} \mathrm{~N} \mathrm{ha}^{-1}$ );

- two wheat cultivars for biscuits production: cultivar Artico (Apsovsementi S.p.A., Voghera, PV, Italy) an early-medium maturity variety, and cultivar Paledor (Apsovsementi S.p.A), a late maturity variety.

The $\mathrm{N}$ rate were established in accordance with the maximum $\mathrm{N}$ applied in integrated production disciplinary $\left(130 \mathrm{~kg} \mathrm{~N} \mathrm{ha}^{-1}\right.$; EEC, 2005) or in nitrate vulnerable zones $\left(170 \mathrm{~kg} \mathrm{Nha}^{-1}\right.$; EEC, 1991).

The slow release fertilizer was Sulfammo $23(23 \%$ total N, with $10 \%$ ammoniacal $\mathrm{N}$ and $13 \%$ ureic N, Timac Agro S.p.A, Atessa, $\mathrm{CH}$, Italy). The nutrient is gradually released due to the presence of a double membrane: the inner organic membrane (containing polyphenolic molecules, MPPA) protects and binds the $\mathrm{N}$ molecules while the outer calcium salt membrane regulates the water intake in function of the soil moisture (Marinaccio et al., 2015).

Top-dressed granular fertilizers were applied to experimental plots by hand. For both variety, an unfertilized control that did not receive any mineral $\mathrm{N}$ fertilization during the growing season was introduced as a spy-control, to indicate the soil fertility and $\mathrm{N}$ availability in the compared environments.

The treatments were assigned to experimental units using a completely randomized block design with four replicates. The plot size was 7 by $1.5 \mathrm{~m}$. The plots were seeded after an autumn plowing $(30 \mathrm{~cm})$ and disk harrowing to prepare a proper seedbed, following a previous crop maize for grain. Planting was conducted in $12 \mathrm{~cm}$ wide rows in October or November at a seeding rate of 450 seeds $\mathrm{m}^{-2}$. The experimental field received $115 \mathrm{~kg} \mathrm{ha}^{-1}$ of $\mathrm{K}_{2} \mathrm{O}$ each year. The weed control was conducted with isoproturon (3-(4-isopropylphenyl)-1,1-dimethylurea or 3-p-cumenyl-1,1-dimethylurea) and diflufenican (2',4'-difluoro-2-( $\alpha, \alpha, \alpha$-trifluorom-tolyloxy)nicotinanilide) at wheat tillering (GS 23).

All the plots were treated with two applications of fungicide: a mixture of azoxystrobin (Methyl (E)-2-\{2 [6-(2-cyanophenoxy)pyrimidin-4-yloxy]phenyl\}-3-methoxyacrylate) and cyproconazole [(2RS,3RS;2SR,3SR)-2-(4chlorophenyl)-3-cyclopropyl-1-(1H-1,2,4-triazol-1-yl) butan-2-ol] (Amistar Xtra, Syngenta Crop Protection S.p.A., Milan, Italy) applied at $0.2 \mathrm{~kg}+0.08 \mathrm{~kg}$ active ingredient (a.i.) $\mathrm{ha}^{-1}$ at steam elongation (GS 34) to control foliar disease, and a mixture of cyproconazole and procloraz $\{\mathrm{N}-\mathrm{Propyl}-\mathrm{N}-[2-$ (2,4,6-trichlorophenoxy)ethyl]-1H-imidazole-1-carboxamide\} (Tiptor Xcell, Syngenta Crop Protection S.p.A., Milan, Italy) applied at $0.02 \mathrm{~kg}+0.17 \mathrm{~kg}$ a.i. $\mathrm{ha}^{-1}$ at heading (GS 55) to avoid Fusarium Head Blight infection and protect flag leaf greenness. The fungicides were applied using a three nozzle precision sprayer (T-Jet 110/04) with a fine mist at a slow walk to ensure effective coverage. The delivery pressure at the nozzle was $324 \mathrm{KPa}$. The sowing, the $\mathrm{N}$ fertilization, the fungicide application and harvest dates are reported in Table 2 for each year and site.

Grain yields were obtained by harvesting with a Walter Wintersteiger cereal plot combine-harvester. A subsample was taken from each plot to determine the grain moisture, thousand kernel weight (TKW) and test weight (TW). The grain yield results were adjusted to a $120 \mathrm{~g} \mathrm{~kg}^{-1}$ moisture content.

The harvested grains were mixed accurately, and $2 \mathrm{~kg}$ grain samples were taken from each plot for the qualitative analyses.

\section{Flag Leaf Greenness}

A chlorophyll meter, Hydro N-Tester (HNT) (Hydro-Agri, now Yara, Oslo, Norway) was used to measure the relative flag leaf greenness after the late $\mathrm{N}$ fertilization.

The HNT is a hand-held instrument that measures the light transmitted by a plant leaf at two different wavelengths $(650$ and $960 \mathrm{~nm}$ ) (Arregui et al., 2006). The ratio of the light transmitted at these wavelengths, in addition to the ratio determined with no sample, is processed by the instrument to produce a digital reading. The HNT values are numerical, dimensionless values that are proportional to the amount of total chlorophyll present in the leaf (Peltonen et al., 1995). 
Table 3. Monthly rainfall and growing degree days (GDD) from sowing (November) to the end of ripening (June) in three growing seasons between 2007 and 2010 in the research sites. $\dagger$

\begin{tabular}{|c|c|c|c|c|c|c|c|c|c|c|}
\hline \multirow[b]{2}{*}{ Site } & \multirow[b]{2}{*}{ Month } & \multicolumn{3}{|c|}{ 2007-2008 } & \multicolumn{3}{|c|}{ 2008-2009 } & \multicolumn{3}{|c|}{$2009-2010$} \\
\hline & & Rainfall & $\begin{array}{l}\text { Rainy } \\
\text { days }\end{array}$ & GDD $\neq$ & Rainfall & $\begin{array}{c}\text { Rainy } \\
\text { days }\end{array}$ & GDD $\uparrow$ & Rainfall & $\begin{array}{l}\text { Rainy } \\
\text { days }\end{array}$ & GDD† \\
\hline \multirow{12}{*}{$\begin{array}{l}\text { Cigliano } \\
\text { sandy loam }\end{array}$} & & $\mathrm{mm}$ & no. & $\Sigma{ }^{\circ} \mathrm{Cd}^{-1}$ & $\mathrm{~mm}$ & no. & $\Sigma{ }^{\circ} \mathrm{Cd}^{-1}$ & $\mathrm{~mm}$ & no. & $\Sigma^{\circ} \mathrm{C} \mathrm{d}^{-1}$ \\
\hline & November & 85 & 4 & 222 & 199 & 13 & 238 & 103 & 6 & 236 \\
\hline & December & 2 & I & 152 & 250 & II & 126 & 53 & 7 & 105 \\
\hline & January & 77 & 10 & $14 \mid$ & 46 & 6 & 88 & 47 & 7 & 58 \\
\hline & February & 23 & 3 & 177 & 74 & 6 & 155 & 96 & 14 & 115 \\
\hline & March & 10 & 1 & 307 & 113 & 8 & 292 & 67 & 9 & 245 \\
\hline & April & $13 \mid$ & 10 & 357 & 253 & 13 & 420 & 56 & 9 & 398 \\
\hline & May & 187 & 14 & 539 & 91 & 4 & 599 & 185 & 12 & 510 \\
\hline & June & 127 & II & 640 & 108 & 8 & 651 & 118 & 9 & 638 \\
\hline & November-June & 640 & 54 & 2534 & 1134 & 69 & 2567 & 725 & 73 & 2305 \\
\hline & November-March & 196 & 19 & 999 & 682 & 44 & 897 & 366 & 43 & 759 \\
\hline & April-June & 445 & 35 & 1535 & 452 & 25 & 1670 & 359 & 30 & 1546 \\
\hline \multirow{11}{*}{$\begin{array}{l}\text { Quargnento } \\
\text { silt loam }\end{array}$} & November & 49 & 4 & 201 & 159 & 10 & 229 & 104 & 8 & 227 \\
\hline & December & 6 & 2 & 90 & 134 & 9 & 60 & 33 & 6 & 73 \\
\hline & January & 136 & 9 & 106 & 57 & 11 & 34 & 38 & 9 & 36 \\
\hline & February & 36 & 3 & $17 \mid$ & 67 & 6 & 127 & 101 & 13 & 87 \\
\hline & March & 4 & I & 264 & 95 & 8 & 273 & 56 & 8 & 224 \\
\hline & April & 125 & 8 & 321 & 144 & 10 & 395 & 41 & 7 & 364 \\
\hline & May & 158 & II & 487 & 3 & 1 & 567 & 65 & 6 & 484 \\
\hline & June & 19 & 6 & 616 & 7 & 1 & 642 & 65 & 5 & 611 \\
\hline & November-June & 532 & 44 & 2257 & 665 & 56 & 2327 & 503 & 62 & 2105 \\
\hline & November-March & 229 & 19 & 832 & 511 & 44 & 723 & 332 & 44 & 646 \\
\hline & April-June & 302 & 25 & 1425 & 154 & 12 & 1604 & I7| & 18 & 1458 \\
\hline \multirow{11}{*}{$\begin{array}{l}\text { Poirino } \\
\text { sandy silt loam }\end{array}$} & November & 63 & 5 & 206 & 160 & 10 & 225 & 79 & 6 & 223 \\
\hline & December & I & $\mathrm{I}$ & 124 & 188 & II & 112 & 35 & 8 & 92 \\
\hline & January & 71 & 9 & 127 & 50 & 9 & 62 & 56 & 8 & 39 \\
\hline & February & 16 & 3 & 163 & 37 & 6 & $|5|$ & 79 & 12 & 96 \\
\hline & March & 7 & 3 & 281 & 85 & 7 & 286 & 58 & 9 & 228 \\
\hline & April & 129 & 10 & 320 & 218 & 15 & 379 & 45 & 7 & 381 \\
\hline & May & 181 & 13 & 501 & 26 & 4 & 584 & 108 & II & 487 \\
\hline & June & 136 & 12 & 607 & 95 & 5 & 635 & 140 & 9 & 604 \\
\hline & November-June & 604 & 56 & 2328 & 859 & 67 & 2433 & 600 & 70 & 2149 \\
\hline & November-March & 159 & 21 & 900 & 520 & 43 & 835 & 307 & 43 & 677 \\
\hline & April-June & 445 & 35 & 1428 & 339 & 24 & 1598 & 293 & 27 & 1472 \\
\hline
\end{tabular}

† Source: Rete Agrometeorologica del Piemonte- Regione Piemonte- Assessorato Agricoltura- Settore Fitosanitario, sezione di Agrometeorologia. ¥ GDD: Accumulated growing degree days for each month using a $0^{\circ} \mathrm{C}$ base.

Readings were taken using the HNT at mid-length of the flag leaf from 30 randomly selected plants per plot. The HNT measurements were performed at different reproductive stages: the beginning of heading (GS 52), the milk (GS 75), and the dough stage (GS 85).

The area under the leaf greenness curve (AULGC) was calculated for each treatment, starting from the HNT measurements conducted during crop maturation, using the following formula:

$$
\mathrm{AULGC}=\sum_{i}^{n-1}\left\{\left[\left(R_{i}+R_{i+1}\right) / 2\right]\left(t_{i+1}-t_{i}\right)\right\}
$$

where $R i$ is the average HNT reading value of the $i$ th record, $R_{i+1}$ is the average HNT reading value of the $i+1$ th record, $t_{i+1}-t_{i}$ is the time of day between the $i$ th record and the $i+l$ th record and $n$ is the number of observations.

\section{Small-Scale Quality Analyses}

Test weight (TW) was determined by means of a DickeyJohn GAC2000 grain analysis meter (Dickey-John Corp., Auburn, IL), using the supplied program and after a validation with reference materials. Thousand kernel weight (TKW) was determined on two 100-kernel sets for each sample, by using an electronic balance.

Grain samples $(50 \mathrm{~g})$ from each plot were milled using a Retsch ZM 200 (Retsch GmbH, Haan, Germany), fitted with a $1 \mathrm{~mm}$ aperture sieve, and the resulting wholemeal has analyzed by near-infrared reflectance spectroscopy, using a NIRSystem 6500 monochromator (Foss-NIRSystems, Silver Spring, MD). Grain protein content (GPC; $\mathrm{N} \times 5.7$, dry matter basis) and hardness were determined according to AACC 39-10 and AACC 39-70A, respectively (AACC, 2000). All analyses were performed in duplicate. 


\section{Large-Scale Quality Analyses}

Only cultivar Artico was taken into consideration for largescale analyses production, since it is the reference cultivar for Italian mills, as far as the wheat for biscuit is concerned. The four replicates for each entry unit (treatment) were bulked and milled with a Bona $4 \mathrm{RB}$ (Bona, Monza, Italy) experimental mill, after tempering according to their hardness. The rheological properties of the flour were evaluated using a Chopin alveograph, according to ICC-121 and a Brabender farinograph, according to ICC-115-D (ICC, 1992).

\section{Statistical Analysis}

The normal distribution and homogeneity of variances were verified for each trial by performing the Kolmogorov-Smirnov normality test and the Levene test, respectively. An ANOVA was utilized to compare all the recorded parameters, using a completely randomized block design, in which the treatment, the cultivars and the type of soil were the independent variables. The ANOVA was conducted separately for the three investigated growing seasons. Multiple comparison tests were performed, according to the REGW-Q test, on the treatment and type of soil means. The SPSS statistical package for Windows, Version 19.0 (SPSS Inc., Chicago, IL), was used for the statistical analysis.

\section{RESULTS}

\section{Weather Conditions and Natural Nitrogen Occurrence in the Soil}

The monthly rainfall and growing degree days (GDD) observed at the three experimental sites over the three growing seasons, are reported in Table 3. The total rainfall that occurred in the period between wheat sowing (November) and vegetative regrowth (March) are the main differences in the three growing seasons. The 2008-2009 growing season experienced the highest total rainfall $(>500 \mathrm{~mm})$ in this period and this was followed by $2009-2010(300-400 \mathrm{~mm})$ and then by $2007-2008(<250$ $\mathrm{mm})$. However, higher rainfall occurred in the 2007-2008 growing season from stem elongation to the end of the ripening stage (from April to June), compared to the 2008-2009 and 2009-2010 growing seasons. The GDD varied between years, with the greatest value in 2008-2009, and this was followed by 2007-2008 and then by 2009-2010.

The total rainfall and GDD also differed between sites, with the highest rainfall level and GDD consistently observed in Cigliano (Sa-Lo) for the three growing seasons.

To characterize the natural $\mathrm{N}$ occurrence in the soil in each experiment, the AULGC curve and the grain yield of the unfertilized control are reported in Table 1. The 2007-2008 growing season was characterized by the highest AULGC and grain yield values in the spy-control plots $(0 \mathrm{~N})$, while the 2008-2009 growing season reported the lowest grain yield in all the compared sites. The 2009-2010 growing season showed intermediate values of both parameters, with the exception of the AULGC curve in the silt loam soil, which recorded the lowest AULGC value, although the grain yield was higher than expected for a good autumn tillering.

\section{Ear Density}

The ANOVA did not show any significant effect of the $\mathrm{N}$ fertilization and cultivar on the final ear density for the 2007 2008 or 2008-2009 growing seasons (Table 4). A significant $(P=0.001)$ interaction between $\mathrm{N}$ fertilization, cultivar and

Table 4. Analysis of variance for ear density, area under the leaf greenness curve (AULGC), grain yield, thousand kernel weight (TKW), test weight (TW), grain protein content (GPC) and grain hardness; field experiments carried out in site with different soil textures in northwestern Italy in the 2007 to 2010 period. $\dagger$

\begin{tabular}{|c|c|c|c|c|c|c|c|c|}
\hline Growing season & Factor & Ear density & AULGC & Grain yield & TKW & TW & GPC & Hardness \\
\hline & & ear $\mathrm{m}^{-2}$ & & $\mathrm{t} \mathrm{ha}^{-\mathrm{I}}$ & $g$ & $\mathrm{~kg} \mathrm{hL}^{-1}$ & $\%$ & \\
\hline \multirow[t]{7}{*}{$2007-2008$} & $\mathrm{~N}$ fertilization & 0.128 & $<0.001$ & 0.578 & 0.644 & 0.865 & $<0.001$ & 0.044 \\
\hline & Cultivar (cv.) & 0.088 & $<0.001$ & 0.001 & 0.110 & 0.046 & $<0.001$ & 0.000 \\
\hline & site & 0.445 & $<0.001$ & $<0.001$ & $<0.001$ & $<0.001$ & $<0.001$ & 0.000 \\
\hline & $\mathrm{N} \times \mathrm{cv}$ & 0.700 & 0.079 & 0.492 & 0.658 & 0.738 & $0.75 I$ & 0.575 \\
\hline & $\mathrm{N} \times$ site & 0.110 & 0.617 & 0.499 & 0.173 & 0.935 & $<0.001$ & 0.533 \\
\hline & cv. $\times$ site & 0.108 & 0.005 & 0.002 & 0.068 & 0.001 & 0.006 & $<0.001$ \\
\hline & $\mathrm{N} \times \mathrm{cv} . \times$ site & 0.525 & 0.139 & 0.708 & 0.301 & 0.773 & 0.764 & 0.339 \\
\hline \multirow[t]{7}{*}{ 2008-2009 } & $\mathrm{N}$ fertilization & 0.774 & $<0.001$ & $<0.001$ & 0.120 & 0.561 & $<0.001$ & $<0.001$ \\
\hline & cultivar & 0.204 & $<0.001$ & $<0.001$ & $<0.001$ & $<0.001$ & 0.001 & 0.443 \\
\hline & site & $<0.001$ & $<0.001$ & 0.630 & $<0.001$ & $<0.001$ & $<0.001$ & $<0.001$ \\
\hline & $\mathrm{N} \times \mathrm{cv}$ & 0.940 & 0.307 & 0.645 & 0.656 & 0.357 & 0.373 & 0.690 \\
\hline & $\mathrm{N} \times$ site & 0.993 & 0.094 & 0.331 & 0.132 & 0.348 & 0.132 & 0.438 \\
\hline & $\mathrm{cv} \times$ site & 0.528 & 0.071 & 0.071 & 0.001 & 0.006 & 0.015 & 0.332 \\
\hline & $\mathrm{N} \times \mathrm{cv} . \times$ site & 0.430 & 0.748 & 0.950 & 0.838 & 0.512 & 0.068 & 0.502 \\
\hline \multirow[t]{7}{*}{ 2009-2010 } & $\mathrm{N}$ fertilization & $<0.001$ & $<0.001$ & 0.006 & 0.908 & 0.155 & $<0.001$ & $<0.001$ \\
\hline & cultivar & $<0.001$ & $<0.001$ & $<0.001$ & 0.248 & $<0.001$ & 0.014 & $<0.001$ \\
\hline & site & 0.049 & $<0.001$ & $<0.001$ & $<0.001$ & $<0.001$ & $<0.001$ & 0.760 \\
\hline & $\mathrm{N} \times \mathrm{cv}$ & $<0.001$ & 0.315 & 0.573 & 0.691 & 0.240 & 0.649 & 0.993 \\
\hline & $\mathrm{N} \times$ site & 0.456 & 0.111 & 0.644 & 0.334 & 0.983 & 0.215 & 0.253 \\
\hline & $\mathrm{cv} . \times$ site & 0.501 & $<0.001$ & 0.001 & 0.009 & $<0.001$ & $<0.001$ & $<0.001$ \\
\hline & $\mathrm{N} \times \mathrm{cv} . \times$ site & 0.001 & 0.094 & 0.636 & 0.640 & 0.732 & 0.996 & 0.553 \\
\hline
\end{tabular}

$\dagger$ The data reported in the table refers to the level of significance $(P)$. 
site was observed for 2009-2010. No difference was observed between the different combinations of cultivar and $\mathrm{N}$ fertilization strategy in Quargnento (Si- Lo), while the slow release fertilizer application (T4) significantly increased the ear density compared to the split $\mathrm{N}$ fertilization with ammonium nitrate in the Poirino ( $\mathrm{Sa}-\mathrm{Si}-\mathrm{Lo}$ ) for both cultivars (data not shown). The T4 treatment in Cigliano (Sa-Lo) did not increase ear density compared to T2, while T3 had a significantly higher ear density than T2, but only for cultivar Paledor.

\section{Leaf Greenness}

The ANOVA showed a significant effect of $\mathrm{N}$ fertilization strategy, cultivar, and site on the AULGC value recorded during the reproductive stages, for all the compared growing seasons (Table 4). In the 2007-2008 growing season, the crop greenness during the maturation stages was significantly higher for the higher $\mathrm{N}$ fertilization rate with split ammonium nitrate (T3) and with the slow release fertilizer (T4), compared to the T2 and T1 treatments (Table 5). In the 2008-2009 and 2009-2010 growing seasons, the AULGC values increased

Table 5. Effect of $\mathrm{N}$ fertilization on ear density, area under the leaf greenness curve (AULGC), grain yield, thousand kernel weight (TKW), test weight (TW), grain protein content (GPC) and grain hardness of wheat for biscuits; field experiments carried out in site with different soil textures in northwestern Italy in the 2007-2010 period.

\begin{tabular}{|c|c|c|c|c|c|c|c|c|c|}
\hline Growing season & Factor & $\begin{array}{l}\text { Source of } \\
\text { variation }\end{array}$ & Ear density & AULGC & Grain yield & TKW & TW & GPC & Hardness \\
\hline & & & ear $\mathrm{m}^{-2}$ & & $\mathrm{t} \mathrm{ha}^{-1}$ & $g$ & $\mathrm{~kg} \mathrm{hL}^{-1}$ & $\%$ & \\
\hline \multirow[t]{12}{*}{ 2007-2008 } & $\mathrm{N}$ fertilization $\dagger$ & TI & 534a & $21485 c$ & $6.5 a$ & $35.3 a$ & $69.9 a$ & $13.4 \mathrm{c}$ & $18.3 b$ \\
\hline & & $\mathrm{T} 2$ & $529 a$ & $22117 b$ & $6.5 a$ & $35.8 \mathrm{a}$ & $69.5 a$ & $13.7 b$ & I7.8ab \\
\hline & & T3 & $593 a$ & $22660 a$ & $6.5 \mathrm{a}$ & $34.8 \mathrm{a}$ & $69.6 a$ & $14.0 \mathrm{a}$ & $20.9 a$ \\
\hline & & $\mathrm{T} 4$ & $557 a$ & $22563 a$ & $6.7 \mathrm{a}$ & $35.8 \mathrm{a}$ & $69.5 \mathrm{a}$ & $13.4 \mathrm{c}$ & $19.2 \mathrm{ab}$ \\
\hline & & sem $\S$ & 126 & 1238 & 1.0 & 3.5 & 2.9 & 0.7 & 6.9 \\
\hline & cultivar & Artico & $540 \mathrm{a}$ & $21022 b$ & $6.8 \mathrm{a}$ & $34.9 a$ & $70.0 \mathrm{a}$ & $13.2 b$ & $13.6 \mathrm{~b}$ \\
\hline & & Paledor & $567 a$ & $23391 \mathrm{a}$ & $6.3 \mathrm{a}$ & $35.9 a$ & $69.3 b$ & $14.0 \mathrm{a}$ & $24.5 a$ \\
\hline & & sem§ & 89 & 875 & 0.7 & 2.5 & 2.0 & 0.5 & 4.9 \\
\hline & siteף & Cigliano & $534 a$ & $23867 a$ & $7.6 \mathrm{a}$ & $37.2 \mathrm{a}$ & $72.2 \mathrm{a}$ & $13.0 c$ & 7.Ic \\
\hline & & Quargnento & $55 \mathrm{la}$ & $208 \mathrm{Ilc}$ & $6.0 \mathrm{~b}$ & $35.4 b$ & $67.9 c$ & $13.7 b$ & $36.9 \mathrm{a}$ \\
\hline & & Poirino & $575 a$ & $2194 \mathrm{Ib}$ & $6.1 b$ & $33.7 c$ & $68.8 b$ & $14.1 \mathrm{a}$ & $13.2 b$ \\
\hline & & sem§ & 109 & 1072 & 0.9 & 3.0 & 2.5 & 0.6 & 6.0 \\
\hline \multirow[t]{12}{*}{ 2008-2009 } & $\mathrm{N}$ fertilization & $\mathrm{TI}$ & $334 a$ & $17638 c$ & $4.4 c$ & $36.9 a$ & $74.2 \mathrm{a}$ & $10.6 c$ & $10.1 \mathrm{c}$ \\
\hline & & $\mathrm{T} 2$ & $341 \mathrm{a}$ & 19426b & $4.9 b$ & $36.6 a$ & $74.4 \mathrm{a}$ & $11.3 b$ & $12.5 b$ \\
\hline & & T3 & $352 a$ & $20782 a$ & $5.3 a$ & $35.6 \mathrm{a}$ & $74.5 \mathrm{a}$ & $12.2 \mathrm{a}$ & I4.Ia \\
\hline & & $\mathrm{T} 4$ & $354 a$ & $17919 c$ & $4.8 b$ & $36.8 \mathrm{a}$ & $74.0 \mathrm{a}$ & $10.6 c$ & $10.4 \mathrm{c}$ \\
\hline & & sem & 88 & $108 \mid$ & 0.6 & 2.7 & 1.4 & 0.6 & 3.8 \\
\hline & cultivar & Artico & $35 \mathrm{Ia}$ & I7980b & $4.6 \mathrm{~b}$ & $35.7 b$ & $73.7 b$ & $10.8 \mathrm{~b}$ & II.Ia \\
\hline & & Paledor & $338 a$ & $19902 a$ & $5.1 \mathrm{a}$ & $37.3 a$ & $74.9 \mathrm{a}$ & $11.5 \mathrm{a}$ & $12.5 \mathrm{a}$ \\
\hline & & sem§ & 62 & 764 & 0.4 & 1.9 & 1.0 & 0.4 & 2.7 \\
\hline & siteף & Cigliano & $382 a$ & $19448 a$ & $4.8 b$ & $38.0 \mathrm{a}$ & $75.5 a$ & II.0b & $12.7 \mathrm{~b}$ \\
\hline & & Quargnento & $349 b$ & $18245 b$ & $4.2 c$ & $36.5 b$ & $75.3 a$ & $10.5 c$ & $14.9 \mathrm{a}$ \\
\hline & & Poirino & $305 c$ & $19128 \mathrm{a}$ & $5.6 a$ & $34.9 c$ & $72.0 \mathrm{~b}$ & $12.0 \mathrm{a}$ & $7.9 c$ \\
\hline & & sem $\S$ & 76 & 936 & 0.5 & 2.3 & 1.2 & 0.5 & 3.3 \\
\hline \multirow[t]{12}{*}{ 2009-2010 } & $\mathrm{N}$ fertilization & TI & $357 c$ & $19187 c$ & $5.1 b$ & $40.9 a$ & $77.9 a$ & $11.3 c$ & $20.1 \mathrm{c}$ \\
\hline & & $\mathrm{T} 2$ & $379 b$ & $2090 \mathrm{lb}$ & $5.6 a$ & $40.9 a$ & $78.2 \mathrm{a}$ & $12.0 \mathrm{~b}$ & $22.6 b$ \\
\hline & & T3 & $392 b$ & $22307 a$ & $5.7 \mathrm{a}$ & $4 I .1 \mathrm{a}$ & $78.5 a$ & $12.6 \mathrm{a}$ & $26.5 a$ \\
\hline & & $\mathrm{T} 4$ & $413 a$ & I9948c & $5.7 \mathrm{a}$ & $41.5 a$ & $78.1 \mathrm{a}$ & $11.4 \mathrm{c}$ & $22.3 b$ \\
\hline & & sem§ & 58 & 1177 & 1.1 & 4.4 & 1.5 & 0.7 & 5.8 \\
\hline & cultivar & Artico & $380 b$ & $19743 b$ & $5.2 b$ & $40.8 a$ & $77.3 b$ & $11.9 b$ & $24.3 b$ \\
\hline & & Paledor & $391 a$ & $21428 a$ & $5.9 a$ & $41.4 \mathrm{a}$ & $78.9 a$ & $11.7 \mathrm{a}$ & $21.5 a$ \\
\hline & & sem§ & $4 I$ & 833 & 0.8 & 3.1 & I.I & 0.5 & 4.1 \\
\hline & siteף & Cigliano & $447 a$ & $247 \mid 4 a$ & $8.4 a$ & $43.0 \mathrm{a}$ & $80.3 a$ & $11.3 c$ & $23.1 \mathrm{a}$ \\
\hline & & Quargnento & $357 b$ & $17317 c$ & $3.5 c$ & $42.9 a$ & $79.2 b$ & $11.8 \mathrm{~b}$ & $23.0 \mathrm{a}$ \\
\hline & & Poirino & $352 b$ & $19725 b$ & $4.7 b$ & $37.3 b$ & $75.0 c$ & $12.3 \mathrm{a}$ & $22.5 a$ \\
\hline & & sem $\S$ & 50 & 1020 & 0.9 & 3.8 & 1.3 & 0.6 & 5.1 \\
\hline
\end{tabular}

† The reported values of the $N$ fertilization factor for each experiment are based on 24 replications ( 2 cultivars $\times 3$ sites $\times 4$ repetitions), the values of the cultivar factor are based on 48 replications ( 4 treatments $\times 3$ sites $\times 4$ repetitions), while the values of the site factor are based on 32 replications (4 treatments $\times 2$ cultivars $\times 4$ repetitions).

$\ddagger$ Means followed by different letters are significantly different (the level of significance is shown in Table 4).

$\S$ sem: standard error of mean.

II site: Cigliano sandy loam, Quargnento silt loam, Poirino sandy silt loam. 
significantly and proportionally with the increase in the $\mathrm{N}$ dispensed as ammonium nitrate. Moreover, in these growing seasons, a slow release fertilizer application (T4) showed similar AULGC values to those observed with the lower $\mathrm{N}$ rate using ammonium nitrate (T1) and significantly lower values to those of the T3 and T4 treatments.

In all the growing seasons cultivar Paledor, a late maturity, showed higher AULGC values than cultivar Artico; moreover Cigliano showed the highest AULGC, and this was followed by experiments performed in Quargnento and Poirino.

The interactions between the $\mathrm{N}$ fertilization and cultivar or site were not significant.

\section{Grain Yield and Yield Parameters}

The ANOVA showed a significant effect of $\mathrm{N}$ fertilization on grain yield in the 2008-2009 and 2009-2010 growing seasons, while in the 2007-2008 season, which was characterized by less rainfall during vegetative growth, the differences were not significant (Table 4). In the 2008-2009 season, grain yield was significantly and proportionally affected by the total $\mathrm{N}$ rate (Table 5). In the 2009-2010 growing season, grain yield was significantly lower for the $\mathrm{T} 1$ treatment compared to the others with a higher $\mathrm{N}$ rate.

No significant differences were observed in any experiment for the same $\mathrm{N}$ rate $\left(130 \mathrm{~kg} \mathrm{~N} \mathrm{ha}^{-1}\right)$ between the split fertilization (T2) or the application of a slow release fertilizer (T4).

Cultivar Artico was more productive than cultivar Paledor in the 2007-2008 growing season. However, in the 20082009 and 2009-2010 seasons the late maturity variety (cultivar Paledor) resulted in a significantly higher grain yield. The highest grain yield was recorded in Cigliano in the 2007-2008 and 2009-2010 growing seasons and in Poirino in 2008-2009.

Table 6. Effect of $\mathrm{N}$ fertilization on the grain protein content (GPC) of wheat for biscuits in site soils with different textures; field experiments carried out in site with different soil textures in the 2007-2008 period.

\begin{tabular}{|c|c|c|c|c|}
\hline \multirow[b]{2}{*}{ Factor } & \multirow{2}{*}{$\begin{array}{c}\text { Source } \\
\text { of } \\
\text { variation }\end{array}$} & \multicolumn{3}{|c|}{ Site† } \\
\hline & & Cigliano & Quargnento & Poirino \\
\hline & & & $\%$ & 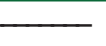 \\
\hline \multirow[t]{6}{*}{$\mathrm{N}$ fertilization $\ddagger$} & TI & $12.6 c \S$ & $13.6 \mathrm{a}$ & $14.1 \mathrm{a}$ \\
\hline & $\mathrm{T} 2$ & $13.3 \mathrm{~b}$ & $13.9 \mathrm{a}$ & $14.0 \mathrm{a}$ \\
\hline & $\mathrm{T} 3$ & $13.9 \mathrm{a}$ & $13.8 \mathrm{a}$ & $14.2 \mathrm{a}$ \\
\hline & $\mathrm{T} 4$ & $12.4 \mathrm{c}$ & $13.6 \mathrm{a}$ & $14.2 \mathrm{a}$ \\
\hline & $P(F$ test $)$ & $<0.001$ & 0.565 & 0.796 \\
\hline & sem & 0.554 & 0.798 & 0.812 \\
\hline \multirow[t]{4}{*}{ Cultivar } & Artico & $12.9 \mathrm{~b}$ & $13.3 \mathrm{~b}$ & $13.6 \mathrm{~b}$ \\
\hline & Paledor & $13.2 \mathrm{a}$ & $14.2 \mathrm{a}$ & $14.6 \mathrm{a}$ \\
\hline & $P(F$ test $)$ & 0.003 & $<0.001$ & $<0.001$ \\
\hline & sem & 0.392 & 0.564 & 0.574 \\
\hline
\end{tabular}

$\begin{array}{lllll}\mathrm{N} \times \text { cultivar } & P(F \text { test }) & 0.113 & 0.932 & 0.981\end{array}$

† site: Cigliano sandy loam, Quargnento silt loam, Poirino sandy silt loam.

$\ddagger$ The reported values of the $\mathrm{N}$ fertilization factor for each experiment are based on eight replications ( 2 cultivars $\times 4$ repetitions), while the values of the cultivar factor are based on 16 replications ( 4 treatments $x$ 4 repetitions).

$\S$ Means followed by different letters are significantly different (the level of significance is shown in the table).

II sem: standard error of mean.
The site characterized by the silt loam soil (Quargnento) was in general the least productive. The interactions between the $\mathrm{N}$ fertilization and cultivar or site were not significant.

The ANOVA did not show a significant effect of the $\mathrm{N}$ fertilization on TKW or TW, in any growing seasons. Cultivar Paledor showed significantly higher TW than cultivar Artico in the 20082009 and 2009-2010 growing seasons, while 2007-2008 showed on opposite trend. The sandy loam soil of Cigliano site resulted in the highest TKW and TW in each growing season.

\section{Kernel and Flour Quality Traits}

The ANOVA showed a significant effect of $\mathrm{N}$ fertilization strategy, cultivar and site on the GPC for all the compared growing seasons (Table 4).

In the 2007-2008 growing season, the interaction between $\mathrm{N}$ fertilization and site was significant $(P<0.001)$ : no significant differences were recorded in Quargnento (Si- Lo) or Poirino (Sa-Si- Lo), while the GPC in Cigliano experiment (Sa- Lo) was affected significantly and directly by the total rate of $\mathrm{N}$ distributed as ammonium nitrate (Table 6). Conversely, the use of the slow release fertilizer (T4) in Cigliano resulted in a significantly lower GPC then the same $\mathrm{N}$ applied as ammonium nitrate (T3).

The GPC in the 2008-2009 and 2009-2010 growing seasons was also significantly increased by the total $\mathrm{N}$ distributed (Table 5). However, in all three sites, when taking in account the same $\mathrm{N}$ rate $\left(130 \mathrm{~kg} \mathrm{~N} \mathrm{ha}^{-1}\right)$, the application of a slow release fertilizer (T4) resulted in a significantly lower GPC (-0.62\%) than the ammonium nitrate fertilizer (T2) but was not significantly different compared to treatment T1 $\left(100 \mathrm{~kg} \mathrm{~N} \mathrm{ha}^{-1}\right)$. The interactions between the $\mathrm{N}$ fertilization and cultivar and/or site were never significant for these growing seasons. The GPC was significantly higher in cultivar Paledor than cultivar Artico in all the compared cases.

The ANOVA showed a significant effect of $\mathrm{N}$ fertilization on grain hardness: this parameter was directly and positively affected by the $\mathrm{N}$ fertilization rate, with moderate differences in the 2007-2008 growing season (only T3 vs. T1 was significant), but higher differences in the other experiments (T1 vs. T2 vs. T3). In the 2008-2009 growing season, the slow release fertilizer (T4) significantly reduced grain hardness compared to the use of ammonium nitrate at the same total $\mathrm{N}$ rate (T2).

In the 2007-2008 and 2009-2010 seasons, cultivar Paledor showed a significantly higher grain hardness than cultivar Artico. The interactions between the $\mathrm{N}$ fertilization and cultivar or site were not significant.

The effect of $\mathrm{N}$ fertilization on the rheological properties of the dough from cultivar Artico is reported in Table 7. When the $\mathrm{N}$ fertilization conducted with the split application of ammonium nitrate is taken into account, the dough strength (W) increased with the total $\mathrm{N}$ rate at the stem elongation stage in each experiment, but particularly in the 2008-2009 and 2009-2010 growing seasons. In these growing seasons, the fertilization with a slow release fertilizer at tillering (T4) led to lower W values compared to the split application of ammonium nitrate at the same $\mathrm{N}$ rate (T2), but were closer to those obtained applying a total lower $\mathrm{N}$ amount (T1).

In the 2007-2008 growing season, with the exception of T1 in Quargnento, none of the compared treatments was able to 
Table 7. Effect of $\mathrm{N}$ fertilization on the alveographic (P, tenacity; L, extensibility; $\mathrm{W}$, dough strength) and farinographic parameters of wheat for biscuits; field experiments carried out in site with different soil textures in northwestern Italy in the 2007 to 2010 period. $\dagger$

\begin{tabular}{|c|c|c|c|c|c|c|c|c|c|c|c|}
\hline \multirow[b]{2}{*}{ Growing season } & \multirow[b]{2}{*}{ Site } & \multirow[b]{2}{*}{$\begin{array}{l}\text { N Fertili- } \\
\text { zation }\end{array}$} & \multirow{2}{*}{$\begin{array}{c}\text { Flour } \\
\text { protein } \\
\text { content }\end{array}$} & \multicolumn{4}{|c|}{ Chopin alveograph } & \multicolumn{4}{|c|}{ Brabender farinograph } \\
\hline & & & & $P$ & L & $\mathrm{P} / \mathrm{L}$ & W & $\begin{array}{c}\text { Water } \\
\text { absorption }\end{array}$ & $\begin{array}{l}\text { Development } \\
\text { time }\end{array}$ & Stability & $\begin{array}{c}\text { Degree of } \\
\text { softening }\end{array}$ \\
\hline & & & $\%$ & $-m$ & $\mathrm{~m}-$ & & $\mathrm{J} 10^{-4}$ & $\%$ & $\longrightarrow \min$ & 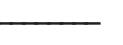 & $\mathrm{BU} \ddagger$ \\
\hline \multirow[t]{12}{*}{ 2007-2008 } & \multirow{4}{*}{$\begin{array}{l}\text { Cigliano } \\
\text { sandy loam }\end{array}$} & TI & 10.2 & 46 & 130 & 0.35 & 156 & 51.3 & 1.5 & 3.2 & 79 \\
\hline & & $\mathrm{T} 2$ & 10.8 & 47 & 122 & 0.39 & 170 & 51.5 & 1.3 & 2.6 & 68 \\
\hline & & T3 & 11.2 & 47 & 119 & 0.39 & 170 & 52.2 & 1.5 & 12.3 & 42 \\
\hline & & $\mathrm{T} 4$ & 10.2 & 43 & 127 & 0.34 & 146 & 51.4 & 1.2 & 6.5 & 64 \\
\hline & \multirow{4}{*}{$\begin{array}{l}\text { Quargnento } \\
\text { silt loam }\end{array}$} & TI & 10.9 & 35 & 125 & 0.28 & 101 & 51.8 & 1.6 & 6.6 & 75 \\
\hline & & $\mathrm{T} 2$ & II.I & 35 & 156 & 0.22 & 114 & 51.9 & 1.9 & 6.4 & 70 \\
\hline & & T3 & 11.0 & 38 & 153 & 0.25 & 126 & 52.0 & 1.8 & 6.4 & 70 \\
\hline & & $\mathrm{T} 4$ & II.I & 35 & 168 & 0.21 & 126 & 51.7 & 1.8 & 6.8 & 66 \\
\hline & \multirow{4}{*}{$\begin{array}{l}\text { Poirino } \\
\text { sandy silt } \\
\text { loam }\end{array}$} & TI & 10.7 & 38 & 165 & 0.23 & 134 & 52.7 & 1.7 & 5.8 & 82 \\
\hline & & $\mathrm{T} 2$ & 10.8 & 39 & 157 & 0.25 & 135 & 52.7 & 1.5 & 6.2 & 81 \\
\hline & & T3 & 11.2 & 40 & 145 & 0.28 & 138 & 53.7 & 1.6 & 5.9 & 91 \\
\hline & & $\mathrm{T} 4$ & II.4 & 44 & 135 & 0.33 & 142 & 53.4 & 1.7 & 6.0 & 77 \\
\hline \multirow[t]{12}{*}{ 2008-2009 } & \multirow{4}{*}{$\begin{array}{l}\text { Cigliano } \\
\text { sandy loam }\end{array}$} & TI & 7.9 & 37 & 100 & 0.37 & 115 & 49.4 & 1.0 & 1.4 & 106 \\
\hline & & $\mathrm{T} 2$ & 8.6 & 39 & 103 & 0.38 & 127 & 50.0 & I.I & 1.5 & 115 \\
\hline & & T3 & 9.5 & 37 & 123 & 0.30 & 130 & 50.5 & 1.2 & 2.6 & 82 \\
\hline & & $\mathrm{T} 4$ & 8.1 & 39 & 97 & 0.40 & 117 & 49.6 & 0.9 & 1.3 & 122 \\
\hline & \multirow{4}{*}{$\begin{array}{l}\text { Quargnento } \\
\text { silt loam }\end{array}$} & TI & 8.6 & 45 & 58 & 0.78 & 94 & 51.8 & I.I & 1.2 & 124 \\
\hline & & $\mathrm{T} 2$ & 9.1 & 44 & 74 & 0.59 & 121 & 51.9 & 1.3 & 1.4 & 115 \\
\hline & & T3 & 9.4 & 57 & 60 & 0.95 & 123 & 52.0 & 1.3 & 1.7 & 98 \\
\hline & & $\mathrm{T} 4$ & 9.3 & 49 & 54 & 0.91 & 95 & 51.7 & 1.2 & 1.4 & 107 \\
\hline & \multirow{4}{*}{$\begin{array}{l}\text { Poirino } \\
\text { sandy silt } \\
\text { loam }\end{array}$} & TI & 7.5 & 39 & 47 & 0.83 & 75 & 48.7 & 1.0 & I.I & 128 \\
\hline & & $\mathrm{T} 2$ & 7.7 & 45 & 65 & 0.69 & 114 & 48.5 & I.I & 1.3 & 125 \\
\hline & & $\mathrm{T} 3$ & 8.7 & $4 I$ & 107 & 0.38 & $|4|$ & 49.4 & 1.4 & 1.8 & 86 \\
\hline & & $\mathrm{T} 4$ & 7.5 & 43 & 66 & 0.65 & 108 & 48.6 & 1.0 & 1.0 & 114 \\
\hline \multirow[t]{12}{*}{ 2009-20I0 } & \multirow{4}{*}{$\begin{array}{l}\text { Cigliano } \\
\text { sandy loam }\end{array}$} & TI & 7.9 & 33 & 89 & 0.37 & 93 & 47.9 & I.I & 1.5 & 105 \\
\hline & & $\mathrm{T} 2$ & 8.7 & 38 & 76 & 0.50 & 98 & 48.9 & 1.0 & 1.8 & 107 \\
\hline & & T3 & 9.7 & 30 & 153 & 0.20 & 112 & 49.6 & 1.5 & 4.0 & 96 \\
\hline & & $\mathrm{T} 4$ & 8.5 & 30 & 123 & 0.24 & 93 & 48.7 & 1.2 & 1.6 & 127 \\
\hline & \multirow{4}{*}{$\begin{array}{l}\text { Quargnento } \\
\text { silt loam }\end{array}$} & TI & 9 & 20 & 102 & 0.20 & 49 & 48.2 & I.I & 2.2 & 136 \\
\hline & & $\mathrm{T} 2$ & 9.6 & 22 & 112 & 0.20 & 35 & 49.2 & 1.2 & 1.9 & 144 \\
\hline & & T3 & 10 & 21 & 135 & 0.16 & 50 & 49.0 & 1.3 & 3.8 & 114 \\
\hline & & $\mathrm{T} 4$ & 9.0 & 24 & 126 & 0.19 & 61 & 48.9 & 1.2 & 1.8 & 149 \\
\hline & \multirow{4}{*}{$\begin{array}{l}\text { Poirino } \\
\text { sandy silt } \\
\text { loam }\end{array}$} & TI & 9.3 & 32 & 111 & 0.29 & 99 & 49.2 & 1.2 & 2.2 & 94 \\
\hline & & $\mathrm{T} 2$ & 9.6 & 34 & 123 & 0.28 & 113 & 49.0 & 1.3 & 3.4 & 88 \\
\hline & & T3 & 10.7 & 36 & 121 & 0.30 & 117 & 50.6 & 1.3 & 7.4 & 66 \\
\hline & & $\mathrm{T} 4$ & 9.8 & 31 & 127 & 0.24 & 98 & 49.6 & 1.3 & 2.4 & II \\
\hline
\end{tabular}

† The reported data refer to the rheological analysis conducted on merged samples of cultivar Artico, resulting from kernel mixing of four replications of each experiment.

$\ddagger \mathrm{BU}$, Brabender units.

satisfy the optimum quality requirements for the market class

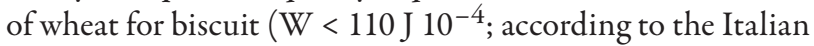
Synthetic Quality Index classification; Foca et al., 2007). In the other two growing seasons, this quality requirement was satisfied over $80 \%$ of the cases with treatments T1 and T4, respectively, while the T2 treatments only fitted the optimum level for this wheat category in $33 \%$ of the cases.

The $\mathrm{P} / \mathrm{L}$ rate was generally low $(<0.5)$ in all the experiments, while higher average values were observed in the trials performed in Quargnento and Poirino in the 2008-2009 growing season, as a consequence of the lower extensibility value (L). No clear effect of $\mathrm{N}$ fertilization has been observed for this parameter. As far as the farinograph parameters are concerned, the $\mathrm{N}$ fertilization rate at stem elongation increased the water absorption and the stability and reduced the degree of softening in all experiments, with the exception of the trails performed in Quargnento and Poirino in the 2007-2008. In the 2008-2009 and 2009-2010 growing seasons, the use of a slow release $\mathrm{N}$ fertilizer on average resulted in less stability than the split application of ammonium nitrate at the same rate. 


\section{DISCUSSION}

This study provides useful information for farmers on how to manage the $\mathrm{N}$ fertilization of wheat for biscuits production, to obtain an improvement in both yield and qualitative traits.

Data collected in nine field experiments, over three growing seasons and in three types of soils, confirm that the environment is the main factor that can influence the qualitative parameters, thus confirming a previous survey conducted in the Washington and Idaho states by Bassett et al. (1989). As expected, the variable grain protein responses over site-years is closely associated to soil $\mathrm{N}$ availability during spring, which is influenced by the interaction of the soil characteristics, the meteorological trends, especially rainfall, and the $\mathrm{N}$ fertilization. Nitrogen soil availability seems to have a more consistent effect on wheat qualitative traits than productive ones: in the growing season characterized by the lowest rainfall (20072008), the interaction between $N$ treatment and site was significant for GPC, but did not affect grain yield. Data recorded under different environments clearly highlight that rainfall during winter and the first part of spring play the most important role on GPC of wheat, followed by the type of soil.

However, $\mathrm{N}$ application strategies could play an important role in the different environments to obtain the qualitative requirements of wheat for biscuits, particularly in the growing season with high rainfall and in the sandier soil. The present study clearly underlines that a negative relationship exists between the $\mathrm{N}$ rate at stem elongation and the qualitative requirements of these market categories. The highest considered $\mathrm{N}$ rate $\left(170 \mathrm{~kg} \mathrm{~N} \mathrm{ha}^{-1}\right)$ consistently increased the GPC and the rheological parameters, above the enduse quality requirement level of this market class in almost all the compared conditions. Furthermore, this $\mathrm{N}$ rate was able to determine significant yield advantages compared to $130 \mathrm{~kg} \mathrm{~N} \mathrm{ha}^{-1}$, but only in the growing season characterized by the highest rainfall level and, consequently, the highest $\mathrm{N}$ leaching. The fertilization with $130 \mathrm{~kg} \mathrm{~N} \mathrm{ha}^{-1}$, led to consistent yield advantage over the different growing seasons compared to the lowest rate obtained in this experiment $\left(100 \mathrm{~kg} \mathrm{~N} \mathrm{ha}^{-1}\right)$, with the exception of the year characterized by a higher natural $\mathrm{N}$ occurrence, in which no productive differences were reported. However, the application of $\mathrm{N}$ at this rate as ammonium nitrate split between wheat tillering and the beginning of stem elongation, resulted in a significant rise in GPC and grain hardness, compared to fertilization at the lower rate of $100 \mathrm{~kg} \mathrm{~N} \mathrm{ha}^{-1}$, and thus increased the risk of not satisfying the qualitative requirements of this market category.

These results are in agreement with other studies on soft wheat performed in the United States (Georgia, Brucker and Morey, 1988), Canada (Alberta, Carefoot et al., 1989), and Denmark (Pedersen and Jørgensen, 2007). According to Borghi et al. (1995) and López-Bellido et al. (2001), who conducted experiments on bread-making wheat, as $\mathrm{N}$ fertilizer rates at stem elongation increase, a rise in GPC and a corresponding increase in $\mathrm{W}$ and the $\mathrm{P} / \mathrm{L}$ ratio can be observed. Moreover, the data collected underline that the $\mathrm{N}$ fertilization rate affects the GPC more than grain yield, thus confirming the data collected by Jia et al. (1996) and Fowler (2003) for high protein wheat. Johnston and Fowler (1991) reported that delaying the spring $\mathrm{N}$ application to the end of stem elongation can promote GPC accumulation more than yield. Moreover, working both on soft and hard wheat, Labuschagne et al. (2006) reported that the total amount of $\mathrm{N}$ seemed to have a greater influence on the protein fractions than different fertilizer application timings.

Farrer et al. (2006) reported that, unlike grain yield and test weight, an important part of GPC variability of soft winter wheat in North Carolina should be attributed to $\mathrm{N}$ management (rate and timing) mainly due to the environmental conditions. These authors reported that low $\mathrm{N}$ rates consistently resulted in low grain protein levels, and these qualitative levels were relatively stable from environments to environments.

Thus, a first recommendation for farmers who produce wheat for biscuits is to avoid the over-application of $\mathrm{N}$ beyond the level required to optimize the yield and economic return. Under high residual soil $\mathrm{N}$ levels, apart from a reduction in $\mathrm{N}$ rates, Sowers et al. (1994) suggest splitting the $\mathrm{N}$ applications and reducing the amount applied at the stem elongation stages, to maintain a high yield while lowering GPC. Since a close relationship exists between AULGC and both grain yield and GPC, the use of chlorophyll readings can help farmers to guide the $\mathrm{N}$ fertilization throughout the season based on the amount of $\mathrm{N}$ available (Peltonen et al., 1995).

Moreover, the data reported in the present study clearly underline that in addition to the $\mathrm{N}$ rate, the fertilizer type and the adopted $\mathrm{N}$ fertilization strategy also affect the GPC and the rheological parameters of grain for biscuits. The application of a slow release $\mathrm{N}$ fertilizer at tillering, instead of a split ammonium nitrate fertilization, did not lead to any advantage or disadvantage in terms of grain yield, thus confirming experiments conducted on soft wheat in the Alberta region (Canada) by McKenzie et al. (2007) and in North Carolina by Cahill et al. (2010). Conversely, the application of a slow release fertilizer at tillering often leads to a lower GPC and better fits the rheological requirements of this wheat category, compared to the application of the same $\mathrm{N}$ rate as ammonium nitrate split between the tillering and stem elongation stages.

These data highlight that the use of a slow release fertilizer for low-protein wheat does not necessarily lead to the risk of increasing the final grain protein due to an extended availability of $\mathrm{N}$ to the plants during grain filling. As far as breadmaking common and durum wheat is concerned, the spring application of a top-dressed slow release fertilizer has not been reported to increase GPC, compared to a conventional fertilizer (Diez et al., 1997; Middleton et al., 2004; Beres et al., 2010; Grant et al., 2012). McKenzie et al. (2010) reported that the top-dressing of polymer-coated urea in early spring instead of un-coated urea, urease inhibitor urea, or ammonium nitrate could lead to a lower grain yield and lower GPC, due to an excessive delay in the release of N. For a successful spring application of slow release fertilizer in wheat, it is necessary that the successive releases of $\mathrm{N}$ into the soil solution should correspond well to the demand of $\mathrm{N}$ in the various growth stages of winter wheat (Yang et al., 2011).

Moreover, the data collected in the present study, have shown that slow release fertilizers applied at tillering, which gradually match the $\mathrm{N}$ crop uptake, reduce the risk of having an excessive GPC and flour strength in wheat. This strategy could help avoid the occurrence of high levels of $\mathrm{N}$ in the soil 
solution immediately after fertilization, which, with the split application of a quickly available $\mathrm{N}$ fertilizer, such as ammonium nitrate at the stem elongation stage, could be responsible for a rise in the protein concentration in wheat kernels.

The data reported in the present study stress the evidence that the enhancement of wheat for biscuits rheological quality, obtained by improving the synchronization of $\mathrm{N}$ availability to the crop demand through the use of a controlled-release fertilizer, is quite consistent in agro-environments that differ in soil texture, fertility, and climatic conditions during the growing seasons. Further studies are required to confirm that the positive effects on the quality of wheat for biscuits could also be obtained with other controlled-release fertilizers, such as nitrification inhibitors and urea-aldeyde products, or other semipermeable polymer coating or organo-mineral $\mathrm{N}$ fertilizers.

A further advantage of slow release fertilizer application at the tillering stage is the potential benefit of increasing the ear density, which was observed in the present field experiments, and which has also been reported for winter wheat by McKenzie et al. (2007) and Ingle et al. (2010).

In conclusion, the results collected from field experiments conducted over different growing seasons and in different sites with different pedo-climatic conditions, have underlined that suitable rheological parameters of wheat for biscuits could be achieved through the split application of a traditional fertilizer with a reduction in the $\mathrm{N}$ rate, although this could limit the productive performances. Conversely, the fertilization strategy of a single application of a slow release fertilizer at tillering is able to better satisfy the qualitative requirements of biscuit production, without causing a grain yield loss. The economic benefits of using a slow release $\mathrm{N}$ fertilizer instead of a traditional one on wheat were generally considered limited or nonexistent, since the cost of fertilizer is higher and yield advantage are not consistent (Khakbazan et al., 2013). However, the results obtained in the present study make this practice attractive for the cultivation of wheat for biscuit production, to fit the qualitative requirements of this wheat category supply chain.

\section{ACKNOWLEDGMENTS}

The authors would like to thank Fabio Carnaroglio, Roberto Capurro, Alessandro Costanzo, Marguerite Jones, Mattia Ciro Mancini, Alessandro Peila, Andrea Pilati, and Francesca Vanara for their precious help and cooperation in the laboratory and field work. The research was conducted with the financial support of the Regione Piemonte, as part of the QUALICHAIN projects.

\section{REFERENCES}

AACC. 2000. Approved methods of the American Association of Cereal Chemists. 10th ed. The Association, St Paul, MN.

Arregui, L.M., B. Lasa, A. Lafarga, I. Irañeta, E. Baroja, and M. Quemada. 2006. Evaluation of chlorophyll meters as tools for $\mathrm{N}$ fertilization in winter wheat under humid Mediterranean conditions. Eur. J. Agron. 24:140-148. doi:10.1016/j.eja.2005.05.005

Bassett, L.M., R.E. Allan, and G.L. Rubenthaler. 1989. Genotype × environment interactions on soft white winter wheat quality. Agron. J. 81:955-960. doi:10.2134/agronj1989.000219620081 $00060022 x$
Beres, B.L., K.N. Harker, G.W. Clayton, E. Bremer, T.T. O’Donovan, R.E. Blackshaw, and A.M. Smith. 2010. Influence of N fertilization method on weed growth, grain yield and grain protein concentration in no-till winter wheat. Can. J. Plant Sci. 90:637-644. doi:10.4141/CJPS10037

Borghi, B., G. Giordani, M. Corbellini, P. Vaccino, M. Guermandi, and G. Toderi. 1995. Influence of crop rotation, manure and fertilizers on bread making quality of wheat (Triticum aestivum L.). Eur. J. Agron. 4:37-45. doi:10.1016/S1161-0301(14)80015-4

Brucker, P.L., and D.D. Morey. 1988. Nitrogen effects on soft red winter wheat yield, agronomic characteristics, and quality. Crop Sci. 28:152-157. doi:10.2135/cropsci1988.0011183X002800010033x

Cahill, S., D. Osmond, R. Weisz, and R. Heiniger. 2010. Evaluation of alternative nitrogen fertilizers for corn and winter wheat production. Agron. J. 102(4):1226-1236. doi:10.2134/ agronj2010.0095

Carefoot, M.J., T. Entz, and J.B. Bole. 1989. Relative efficiency of fertilizer $\mathrm{N}$ and soil nitrate at various depths for the production of soft white wheat. Can. J. Soil Sci. 69:867-874. doi:10.4141/cjss89-087

Contamine, A.S., J. Abecassis, M.-H. Morel, B. Vergnes, and A. Verel. 1995. Effect of mixing conditions on the quality of dough and biscuits. Cereal Chem. 72:516-522.

Diez, J.A., R. Roman, R. Caballero, and A. Caballero. 1997. Nitrate leaching from soils under a maize-wheat-maize sequence, two irrigation schedules and three types of fertilizers. Agric. Ecosyst. Environ. 65:189-199. doi:10.1016/S0167-8809(97)00045-5

Dinnes, D.L., D.L. Karlen, D.B. Jaynes, T.C. Kaspar, J.L. Hatfield, T.S. Colvin, and C.A. Cambardella. 2002. Nitrogen management strategies to reduce nitrate leaching in tiledrained Midwestern soils. Agron. J. 94:153-171. doi:10.2134/ agronj2002.0153

EEC. 1991. Council Directive 91/676/EEC of 12 December 1991 concerning the protection of waters against pollution caused by nitrates from agricultural sources. Official Journal L375:00010008. European Union. http://eur-lex.europa.eu/legal-content/ EN/TXT/?uri=CELEX:31991L0676 (accessed 19 Feb. 2015).

EEC. 2005. Measure 214.1 of Support for Rural Development 2007-13, approved by DGR 44-7485/2007 of Piedmont Region; transposition of Council Directive 2005/1698/EEC of 20 September 2005 on support for rural development by the European Agricultural Fund for Rural Development (EAFRD). Official Journal L277. European Union. http://eur-lex.europa.eu/legal-content/EN/ TXT/?uri=OJ:L:2005:277:TOC (accessed 19 Feb. 2015).

Farrer, D.C., R. Weisz, R. Heiniger, J.P. Murphy, and J.G. White. 2006. Minimizing protein variability in soft red winter wheat. Agron. J. 98(4):1137-1145. doi:10.2134/agronj2006.0039

Foca, G., A. Ulrici, M. Corbellini, M.A. Pagani, M. Lucisano, G.C. Franchini, and L. Tassi. 2007. Reproducibility of the Italian ISQ method for quality classification of bread wheats: An evaluation by expert assessors. J. Sci. Food Agric. 87:839-846. doi:10.1002/jsfa.2785

Fowler, D.B. 2003. Crop nitrogen demand and grain protein concentration of spring and winter wheat. Agron. J. 95:260-265. doi:10.2134/agronj2003.0260

Gaines, C.S. 1991. Associations among quality attributes of red and white soft wheat cultivars across locations and crop years. Cereal Chem. 68:56-59.

Garrido-Lestache, E., R.J. López-Bellido, and L. López-Bellido. 2004. Effect of $\mathrm{N}$ rate, timing and splitting and $\mathrm{N}$ type on bread-making quality in hard red spring wheat under rainfed Mediterranean conditions. Field Crops Res. 85:213-236. doi:10.1016/S0378-4290(03)00167-9

Grant, C.A., R. Wu, F. Selles, K.N. Harker, G.W. Clayton, S. Bittman, B.J. Zebarth, and N.Z. Lupwayi. 2012. Crop yield and nitrogen concentration with controlled release urea and split applications of nitrogen as compared to non-coated urea applied at seeding. Field Crops Res. 127:170-180. doi:10.1016/j.fcr.2011.11.002 
Huebner, F.R., J.A. Bietz, T. Nelsen, G.S. Bains, and P.L. Finney. 1999. Soft wheat quality as related to protein composition. Cereal Chem. 76:650-655. doi:10.1094/ CCHEM.1999.76.5.650

ICC. 1992. Standard methods of the International Association for Cereal Chemistry. ICC, Vienna, Austria.

Igrejas, G., H. Guedes-Pinto, V. Carnide, J. Clement, and G. Branlard. 2002. Genetical, biochemical and technological parameters associated with biscuit quality. II. Prediction using storage proteins and quality characteristics in a soft wheat population. J. Cereal Sci. 36:187-197. doi:10.1006/jcrs.2002.0452

Ingle, H.L., R.T. Koenig, and M.S. Stowe. 2010. Effect of seed-row placement of conventional and polymer-coated urea on winter wheat emergence. Commun. Soil Sci. Plant Anal. 41:887-896. doi:10.1080/00103621003592390

Jia, Y.Q., J.L. Fabre, and T. Aussenac. 1996. Effects of growing location on response of protein polymerization to increased nitrogen fertilization for the common wheat cultivar Soissons: Relationship with some aspects of the bread-making quality. Cereal Chem. 73:526-532.

Johnston, A.M., and D.B. Fowler. 1991. No-till winter wheat production: Response to spring applied nitrogen fertilizer form and placement. Agron. J. 83:722-728. doi:10.2134/agronj1991.0002 $1962008300040015 x$

Khakbazan, M., C.A. Grant, G. Finlay, R. Wu, S.S. Malhi, F. Selles et al. 2013. An economic study of controlled release urea and split applications of nitrogen as compared with non-coated urea under conventional and reduced tillage management. Can. J. Plant Sci. 93:523-534. doi:10.4141/cjps2012-107

Labuschagne, M.T., A. Claassen, and C.S. van Deventer. 1997. Biscuit-making quality of backcross derivatives of wheat differing in kernel hardness. Euphytica 96:263-266. doi:10.1023/A:1003029618430

Labuschagne, M.T., G. Meintjes, and F.P.C. Groenewald. 2006. The influence of different nitrogen treatments on the size distribution of protein fractions in hard and soft wheat. J. Cereal Sci. 43:315-321. doi:10.1016/j.jcs.2005.11.004

López-Bellido, L., R.J. López-Bellido, J.E. Castillo, and F.J. LópezBellido. 2001. Effects of long-term tillage, crop rotation and nitrogen fertilization on bread-making quality of hard red spring wheat. Field Crops Res. 72:197-210. doi:10.1016/ S0378-4290(01)00177-0

López-Bellido, L., R.J. López-Bellido, and R. Redondo. 2005. Nitrogen efficiency in wheat under rainfed Mediterranean conditions as affected by split nitrogen application. Field Crops Res. 94(1):86-97. doi:10.1016/j.fcr.2004.11.004
Marinaccio, F., M. Blandino, and A. Reyneri. 2015. Effect of nitrogen fertilization on yield and quality of durum wheat cultivated in Northern Italy and their interaction with different soils and growing seasons. J. Plant Nutr. In press.

McKenzie, R.H., E. Bremer, A.B. Middleton, P.G. Pfiffner, and R.E. Dowbenko. 2007. Controlled-release urea for winter wheat in southern Alberta. Can. J. Soil Sci. 87:85-91. doi:10.4141/S06-055

McKenzie, R.H., A.B. Middleton, P.G. Pfiffner, and E. Bremer. 2010. Evaluation of polymer-coated urea and urease inhibitor for winter wheat in southern Alberta. Agron. J. 102(4):1210-1216. doi:10.2134/agronj2009.0194

Middleton, A.B., E. Bremer, and R.H. McKenzie. 2004. Winter wheat response to nitrogen fertilizer form and placement in southern Alberta. Can. J. Soil Sci. 84(1):125-131. doi:10.4141/S03-028

Pedersen, L., and J.R. Jørgensen. 2007. Variation in rheological properties of gluten from three biscuit wheat cultivars in relation to nitrogen fertilization. J. Cereal Sci. 46:132-138. doi:10.1016/j. jcs.2007.01.001

Pedersen, L., K. Kaack, M.N. Bergsøe, and J. Adler-Nissen. 2004. Rheological properties of biscuit dough from different cultivars, and relationship to baking characteristics. J. Cereal Sci. 39:37-46. doi:10.1016/S0733-5210(03)00064-X

Peltonen, J., A. Virtanen, and E. Haggrèn. 1995. Using a chlorophyll meter to optimize nitrogen fertilizer application for intensivelymanaged small-grain cereals. J. Agron. Crop Sci. 174:309-318. doi:10.1111/j.1439-037X.1995.tb01118.x

Sowers, K.E., B.C. Miller, and W.L. Pan. 1994. Optimizing yield and grain protein in soft white winter wheat with split nitrogen applications. Agron. J. 86:1020-1025. doi:10.2134/agronj1994. $00021962008600060017 x$

Wang, F.L., and A.K. Alva. 1996. Leaching of nitrogen from slowrelease urea sources in sandy soils. Soil Sci. Soc. Am. J. 60:14541458. doi:10.2136/sssaj1996.03615995006000050024x

Wieser, H., and W. Seilmeier. 1998. The influence of nitrogen fertilization on quantities and proportions of different protein types in wheat flour. J. Sci. Food Agric. 76:49-55. doi:10.1002/ (SICI)1097-0010(199801)76:13.0.CO;2-2

Yang, Y.-C., M. Zhang, L. Zheng, D.-D. Cheng, M. Liu, and Y.-Q. Geng. 2011. Controlled release urea improved nitrogen use efficiency, yield, and quality of wheat. Agron. J. 103:479-485. doi:10.2134/agronj2010.0343

Zadoks, J.C., T.T. Chang, and C.F. Konzak. 1974. A decimal code for the growth stages of cereals. Weed Res. 14:415-421. doi:10.1111/j.1365-3180.1974.tb01084.x 